Sonic Bodies 


\section{SOUND IN HISTORY}

Emma Dillon, Series Editor 


\title{
SONIC BODIES
}

\author{
Text, Music, and Silence in \\ Late Medieval England
}

\author{
Tekla Bude
}

\section{$\overline{\text { PENN }}$}

UNIVERSITY OF PENNSYLVANIA PRESS

PHI L A D E L PH I A 
Copyright (C) 2022 University of Pennsylvania Press

All rights reserved. Except for brief quotations used for purposes of review or scholarly citation, none of this book may be reproduced in any form by any means without written permission from the publisher.

$$
\begin{gathered}
\text { Published by } \\
\text { University of Pennsylvania Press } \\
\text { Philadelphia, Pennsylvania I9I04-4II2 } \\
\text { www.upenn.edu/pennpress }
\end{gathered}
$$

Printed in the United States of America on acid-free paper I0 987765432 I

A Cataloging-in-Publication record is available from the Library of Congress

$$
\begin{aligned}
& \text { ISBN 978-0-8I22-5370-2 (hardback) } \\
& \text { ISBN 978-o-8122-9832-I (eBook) }
\end{aligned}
$$


For Carson, Steve, Biko, Fela, Cala, and Naima 
